\title{
The Christmas Season and the Protestant Churches in England, c. I870-I9I4
}

\author{
by NEIL ARMSTRONG \\ Teesside University \\ E-mail: N.Armstrong@tees.ac.uk
}

\begin{abstract}
Histories of the English Christmas tend to downplay the role of religion in the development of the modern festival. This article examines the place of religion in the popular celebration of Christmas, as well as the provision of worship offered by the Protestant Churches during the festive season. It argues that although some churchmen viewed Christmas pessimistically as part of a broader battle between sacred and secular, the Churches played an important role in the expansion of the urban public culture of Christmas in the late nineteenth century, whilst the doctrine of the incarnation provided a religious framework for the celebration of childhood and domesticity that the festival had come to embody.
\end{abstract}

$\mathrm{S}$ ince the I980s a number of academic and popular histories of the English Christmas have appeared on the market. These stress the importance of the Victorian age to the formation of the modern Christmas festival. The introduction and development of new rituals involving Christmas cards, Christmas trees and the Santa Claus icon have been embedded in broader conceptual frameworks such as the 'invention of tradition' and the evolution of English national identity. In doing so, historians have tended to marginalise the role that religion played in the forging of a festival that was to become an important part of the national culture. Religion has been reduced to little more than a guilt-inspired stimulus to philanthropic activity, and in the most recent study of the English Christmas, Mark Connelly excuses his omission of the Churches by arguing that 'in investigating the history of the national Christmas it was clear that the national Church had very little to do with its formation'.

I would like to thank Professor Arthur Burns, Dr Catriona Kennedy and the anonymous reader for this JournaL for their helpful comments on previous versions of this article.

${ }^{1}$ J. M. Golby and A. W. Purdue, The making of the modern Christmas, London I986; Gavin Weightman and Steve Humphries, Christmas past, London r987; Mark Connelly, Christmas: a social history, London-New York I999, 7. 
Many of the rituals associated with the modern Christmas are undoubtedly secular in nature (if not in origin), but this does not necessarily mean that the Protestant Churches failed to engage in or interact with new and expanding forms of popular culture in the long nineteenth century. ${ }^{2}$ For Anglicans, Christmas remained one of the major occasions of the Christian calendar, and churchgoing at Christmas remained common amongst the middle and upper classes throughout the nineteenth century. However, for certain forms of Protestant dissent Christmas could be something actively to avoid, as the festival was symbolic of Catholic idolatry, Anglican hegemony, plebeian revelry and aristocratic vice. Avoiding Christmas, or promoting a culturally distinctive form of festive celebration, became a way of asserting a Nonconformist identity, although as the nineteenth century progressed, much of the opposition to Christmas dissolved as dissenters began to reconcile themselves to aspects of the English national culture.

This article examines the place of religion in the popular celebration of Christmas as well the provision of worship offered by the Protestant Churches during the festive season, from Advent to the New Year. This allows a study of the build-up to and anticipation of Christmas, combined with the celebration of what the social anthropologist Daniel Miller identifies as a 'twin-peaked' festival, with climaxes on Christmas Day and New Year. ${ }^{3}$ The article draws upon later nineteenth- and early twentieth-century evidence from parish magazines, the local press and other sources from Leeds and York, as well as material from further afield. This Yorkshire evidence demonstrates the difference and convergence in practice both between the Protestant Churches and within Anglicanism. It can be situated amongst a body of scholarship on religious belief and activity at parochial level based on case studies in areas including Croydon, Halifax and Oldham. ${ }^{4}$ Whilst these studies do not ignore Christmas, they have been understandably preoccupied with the wider context of the Churches' response to industrialisation and urbanisation, and with refining and critiquing the secularisation thesis. This makes the study of the relationship between Christmas and the Protestant Churches all the more pressing. During a period in which the celebration of Christmas was expanding and

${ }^{2}$ Christmas was also very important to the Roman Catholic liturgical year, but there is not sufficient space in a journal article to include the English Catholic Church in this discussion.

3 Daniel Miller, 'A theory of Christmas', in Daniel Miller (ed.), Unwrapping Christmas, Oxford 1993,6 .

${ }^{4}$ A. B. Bartlett, 'The churches in Bermondsey, I880-1939', unpubl. PhD diss. Birmingham 1987; Jeffrey Cox, The English Churches in a secular society: Lambeth, 1870-1930, Oxford 1982; S. J. D. Green, Religion in the age of decline: organisation and experience in industrial Yorkshire, I870-I920, Cambridge I996; James Obelkevich, Religion and rural society: South Lindsey, 1825-1875, Oxford 1976; Mark A. Smith, Religion in industrial society: Oldham and Saddleworth, I740-I865, Oxford I994; Sarah C. Williams, Religious belief and popular culture in Southwark, c. $1880-1939$, Oxford 1999 . 
becoming more complex in emotional, material and social terms, the festive season was a potential battleground for the religious marketplace, and a marker of the subtleties of both secularisation and 'discursive Christianity' in private and public context. ${ }^{5}$

The first section is suggestive of the ways in which religion could be central to the expanding Christmas festival of the nineteenth century. The growing importance of the doctrine of the incarnation within Anglicanism, for example, allowed for the promotion of a child-centred view of Christ. This formed part of the process in which Christmas became a celebration of the prevailing middle-class ideology of childhood, ${ }^{6}$ and in turn helped to sanctify the domestic festivity of home and hearth. The second section emphasises parochial activity at Christmas-time, including discussions of two examples of church culture, decorating and carolling, which permeated the popular celebration of the festive season. At the same time church decorating could provoke tensions within the Established Church, whilst carols revealed the fault lines between the sacred and secular understanding of Christmas. The final section highlights the growth of church services during the festive season in the later nineteenth and early twentieth centuries. Particular emphasis is placed upon the importance within Anglicanism of Christmas communion, which in turn fostered a preparatory culture of Advent services. However, the tendency towards convergence during this period also led several Anglican churches to adopt the New Year watch-night service, which was more often the highlight of the festive season in dissenting, particularly Methodist, churches. Watch-nights could potentially be an example of the fusion of the sacred and the secular during the holiday season. At the same time, the contrast between the popular revelries and the solemnity of holy communion, combined with idealised images of innocent children and the domestic hearth confirmed in the minds of some clergymen a rejection of the ideal of a national and inclusive Church in favour of a 'gathered church'. Yet the behaviour which most offended churchmen at Christmas time long predated the modern expansion of the festival, and much of the festivity was relatively easily reconciled within a Christian framework.

Ever since the early Christian Church imposed a liturgical structure on a preexisting calendar of pagan winter festivals, the relationship between the religious and the secular celebration of Christmas has at times been complementary, overlapping and symbiotic, but can always be characterised

${ }^{5}$ Callum G. Brown, The death of Christian Britain: understanding secularisation, I800-2000, London $200 \mathrm{I}$.

${ }^{6}$ Hugh Cunningham, Children and childhood in western society since I50o, Harlow I995. 
as contested. Typically, tensions have arisen from disagreements concerning appropriate personal and collective conduct when marking the anniversary of the birth of Christ. Even in the largely secular culture of contemporary English society, religious feeling can be cited as part of a broader range of authentic values and experiences which are perceived to be either lost or under threat from the corrupting taint of commerce. Historically, this 'battle for Christmas' related to wider contests for religious, moral and social authority involving the Church, elites, emerging social groups and the defence of traditional rights, customs and pastimes by the lower orders. This was further complicated following the Reformation by the emergence of Protestant dissent. Dissenters amplified the concerns of the Church that too many people spent Christmas in idle dissipation or a riotous excess of drunkenness and gluttony, and, in its most extreme form, Protestant dissent rejected the celebration of Christmas entirely, perceiving the festival to be a relic of papal authority for which there was no biblical sanction, and furthermore a celebration that held uncomfortable associations with the powers and privileges of the Anglican Church.

During the long nineteenth century Christmas in England underwent a gradual transformation and expansion representing a shift from communal celebration to festivity centred both in the privacy of the family home and the domains of civil and consumer society. This was a process which contributed to the making of a festival which came to have an integral place in the English national culture, though as a process it was still incomplete by the First World War, as regional, occupational and religious differences militated against uniformity of celebration. Religiosity undoubtedly played an important role in this process, though secularising trends have been noted, including the decline of family prayers in the late nineteenth century and a growing tendency for spiritual belief to become an intensely private matter, unsuited to the dynamics of the shared mirth of Christmas. Evidence from memoirs and diaries suggests an increasing disassociation of expressions of joy from the religious sentiments associated with Christmas. For example, on Christmas Eve 1874 the social reformer Louisa Knightley of Fawsley commented in her diary that 'It is really like Christmas in a story-book, with our happy family party, and the snow on the ground, and the dear old hall hung with garlands, and carol-singing all round, and underlying it all the deep, real joy of our Blessed Lord's birth. ${ }^{77}$ This can be contrasted with evidence from the Edwardian period. Recalling that her family never had carols at Christmas time, Katherine Chorley, who grew up near Manchester, mused: 'Was it because mother's religion was so deep and personal and private that she could not bring herself to expose it to the gaiety of a

7 Louisa Mary Knightley, The journals of Lady Knightley of Fawsley, I856-I884, ed. Julia Cartwright, London I9I5, 272. 
Christmas party? ${ }^{8}$ Such evidence should not, however, be overstated. This formative period in the history of the modern Christmas festival coincided with significant spiritual renewal, particularly in the Church of England. The social problems associated with industrialisation, urbanisation and population growth, combined with the increased strength of Protestant dissent and Roman Catholicism in the second quarter of the nineteenth century, left the Established Church vulnerable to the gradual reduction of its legal privileges. The Anglican response in terms of expanded provision and spiritual vitality was considerable, though divided, particularly between Tractarians and Evangelicals. In particular, the relationship between Christmas and Evangelicalism is complex. Evangelicalism partly inherited the Puritan spirit which led to the banning of Christmas celebrations in the midseventeenth century, and two centuries later dissenting Evangelicals could continue to reject Christmas both as a religious and secular occasion. Equally though, Evangelicalism played a significant role in the development of the family-orientated Christmas in the nineteenth century through its influence on middle-class domestic ideology. ${ }^{9}$ More broadly, religiosity was often so deeply embedded in Victorian culture that contemporaries were able invest acts of feasting and celebration with spiritual significance. For example, Paul Davis highlights how the mid-Victorian generation interpreted Dickens's A Christmas carol, a novella without any explicitly religious scenes, as social gospel, with the Cratchits as the holy family. ${ }^{10}$ Geoffrey Rowell argues that incarnational religion is present in the family scenes of the Carol, where, 'the cornucopia of Christmas food and feasting reflects both the goodness of creation and the joy of heaven'. ${ }^{11}$ Consequently the nature and extent of religiosity in later Victorian and Edwardian family Christmas celebrations remains hard to discern, particularly as not all memoirs address the issue as directly as Katherine Chorley.

The theological transition from atonement to incarnation that occurred within nineteenth-century Anglicanism was of particular significance to the way in which the Established Church engaged with the expanding Christmas festival, especially the emphasis placed on home and hearth and the celebration of childhood. In the early nineteenth century, the emphasis on the doctrine of atonement encouraged a highly emotional response to the anniversary of Christ's birth and, most important, the opportunity that occasion offered for personal redemption. As a contributor to the Lady's Monthly Museum argued in I799, Christian charity and benevolence was a way

${ }^{8}$ Katherine Chorley, Manchester made them, London i970, 33.

9 David Hamlin, 'The structures of toy consumption: bourgeois domesticity and demand for toys in nineteenth-century Germany', Journal of Social History xxxvi (2003), 857-69.

10 Paul Davis, The lives and times of Ebenezer Scrooge, New Haven-London 1990, 78, 8I.

11 Geoffrey Rowell, 'Dickens and the construction of Christmas', History Today xliii (Dec. I993), I7-24 at p. I9. 
of being at once 'qualified and entitled to enjoy a "MERRY CHRISTMAS". ${ }^{12}$ Consequently, clergymen condemned the indulgent excesses associated with the festive season, including drunkenness, gluttony and gambling. Whilst Boyd Hilton has demonstrated that the displacement of the atonement by the incarnation after 1850 placed 'new emphasis on Jesus as man rather than lamb' ${ }^{13}$ in the context of Christmas incarnational religion led some clergy to place increasing emphasis on Jesus as a child and the mystery of his birth, which in turn sanctified the broader associations of Christmas with the domestic rituals of home, family and childhood. In I867 Canon Hey, addressing the York Church Institute, declared 'that quiet cheerfulness of the domestic hearth, and the re-union of scattered members of families was a ... fitting celebration of Him' ${ }^{14}$ In r88 I John Wylde of St Saviour's, Leeds, warned of excess, sin and self-indulgence including drunkenness and gluttony, but also sought an ordering of priorities, beginning with communion and 'the joy in the Holy Child of Bethlehem', followed by 'the family gatherings, the worldly festivities, [and] the moderate feasting' as lower priorities. ${ }^{15}$ At the same time Unitarians at Mill Hill, Leeds, were making similar connections between Christmas, chapel and home in discussing the importance of keeping up the 'true sentiment of Christmas in connexion with the House of God, as well as with our own homes'. ${ }^{16}$ However, there was also an awareness that the Churches were in competition with the domestic interior. The minister Charles Hargrove observed in reference to Christmas services, that 'we must try to make them as suitable to the occasion as possible, so that none may repent of having left fireside and family'. ${ }^{17}$ In I9I3 Canon Austen of York Minster made the link between the incarnation and the Christmas hearth explicit:

The Incarnation shows us that the Lord is with us in the changing scenes associated with the home. It is mostly the place of our chief joys and sorrows, pleasures and pain. There we breathed the breath of life; there happened the events which stand out in childhood. Thence we go forth into the world; thither we used to return to a haven of rest ... Apart from Him there can be no lasting joy, and only those homes where $\mathrm{He}$ is recognised and honoured can really be home. ${ }^{18}$

Some sermons dwelled upon the events of Christ's birth, but in the lateVictorian period the clergy drew upon a wider ideology of childhood prevalent at the time. Childhood had come to be seen as a special time of life characterised by innocence and the power of the imagination, essential to

12 Lady's Monthly Museum ii (I799), 4I.

13 Boyd Hilton, The age of atonement: the influence of Evangelicalism on social and economic thought, I795-I865, Oxford I988, 5, 299.

14 Tork Herald, 28 Dec. I867.

15 St Saviour's Monthly Paper (Dec. I88I).

17 Mill Hill Chapel Monthly Calendar (Dec. 1893).

16 Mill Hill Chapel Record (Jan. I867).

18 Torkshire Herald, 26 Dec. I9I3. 
success and happiness in adulthood. In his address in St Paul's Cathedral in I88o, Dean Church noted that 'at Christmas we rejoiced as children rejoiced'. Thirty years later, Canon Alexander preached a sermon to St Paul's which declared that 'the triumph of Christianity was to be, in many senses, the triumph of childhood', and suggested the desirability of remaining in a childlike state:

The story of the incarnate Christ ... seems to carry with it all that is most closely associated with what we care for in childhood-with gladness, faith, hope, innocence, trustfulness, simplicity, large-eyed wonder, strength made perfect in weakness, contentment with little things. A very childlike child Jesus must have been: dowered with that kind of happiness which you only find in people who are grave and gentle... The message of Christmas meant the recovery of the world's childhood. ${ }^{19}$

Consequently, this evidence suggests that as part of the increasing emphasis that was placed on the incarnation, churchmen provided a theological framework for the middle-class ideology of childhood which was central to the expansion of the Christmas festival in the nineteenth century. It reveals that the Churches were both highly responsive to the popular celebration of Christmas and played a significant role in the development of the meaning attached to seasonal festivity.

\section{II}

The English Churches also played an important role in the expansion of the Christmas philanthropy which was an integral part of the development of a festive urban civic culture in the later nineteenth century. Typical examples from Leeds include the annual distribution of Christmas fare to the poor of the parish of St James, which benefited 408 recipients in 1890, and the Christmas treat to the poor held in Brunswick Wesleyan Chapel, which was established in 1885 , and in 1900 provided a substantial breakfast to 600 children and dinner to $4 \mathrm{I} 5$ aged people. ${ }^{20}$ This culture was complemented by the growth of a leisure and consumer culture of Christmas, and here the tea meetings, bazaars and other festive social events provided by the Churches was also significant. As José Harris argues, the suggestion that the Churches were unable to 'adapt to the new social forces of materialism, democracy, mass organisation, and segregation by social class' is undermined by their strong engagement with 'material concerns'. 'In the field of mass culture', Harris contends, religious bodies could be 'innovators and pioneers'. ${ }^{21}$ Social events, often highly informal, provided the

19 The Times, 26 Dec. I9io.

20 Leeds Mercury, 26 Dec. I89o; 28 Dec. I9oo.

${ }^{21}$ José Harris, Private lives, public spirit: Britain, I870-I9I4, London 1994, I65-6. 
Nonconformist ministry with an opportunity to confirm and celebrate the role of the chapel in the daily lives of dissenters, whilst for the Anglican clergy it formed part of the vision of the parish church as the centre of an organic community. ${ }^{22}$ At the same time, Anglicans and Dissenters often exploited the growing commercial potential of the Christmas season to raise much needed funds. For example, Christmas bazaars were held at the Baptist chapel, Priory Street, York, in I869, and in Leeds at the Wesleyan Methodist Oxford Place Chapel and St Jude's Church, Hunslet, in I87o. ${ }^{23}$

Within Anglicanism one aspect of parochial activity that permeated the broader popular culture of mid-Victorian England was the decoration of churches at Christmas. ${ }^{24}$ Though the Christmas decoration of churches had taken place since at least the late Middle Ages, the practice became much more elaborate in the mid-nineteenth century. ${ }^{25}$ This was demonstrated by E. L. Cutts in his Essay on the Christmas decoration of churches (I862), in which he contrasted the traditional approach of the sextons and the pew-openers of England' where 'the central alley [was] converted into a shady avenue and each pew into a separate bower', with an architectural approach where the lines of the building should be adorned with 'straight and curved lines of evergreen', whilst the font and communion table were to receive extra care and 'richer material' so that they could represent symbols of the sacrament when not in use. During the great festivals they should receive decoration in proportion to their importance, and the birth of Christ placed particular emphasis on the font. ${ }^{26}$ Cutts also viewed church decorating as a way of creating social unity. The making of decorations was as an event that could involve the whole family, but Cutts maintained that it would:

serve a useful moral purpose to associate as many as possible in the work. One of the evils of our day is surely the isolation of class from class - the want of friendly intercourse even among good people of different classes. On the common ground of the parsonage dining-room or the national school-room, you may bring together different ranks of your parishioners and the pleasant bustle and confusion of the work will shake them together, and make them really more intimate in a couple of days than in a century of uncomfortable parties. ${ }^{27}$

Peter Anson has argued that the decoration of churches became so popular in mid-Victorian England because of the broader craze for the gothic style and also because it paralleled the feminine fashion for cluttering the

${ }^{22}$ Smith, Religion in industrial society, I45; Green, Religion in the age of decline, 339.

23 Tork Herald, 24 Dec. I869; Leeds Mercury, 28 Dec. I87o.

24 See, for example, Herbert Vaughan's 'The font and the flowers', illustrated by Leech, Illustrated London Newes, 22 Dec. 1860, and the extended descriptions of church decorations in the Fork Herald in the early to mid-ı87os.

${ }^{25}$ Ronald Hutton, The stations of the sun: a history of the ritual year in Britain, Oxford 1996, 34.

${ }^{26}$ E. L. Cutts, An essay on the Christmas decoration of churches, London I862, I9, 48, 54-5, 6r.

${ }^{27}$ Ibid. 63. 
Victorian home, though the icon of Christmas decorations, the tree, was not used in church in this period. ${ }^{28}$ At the same time, the emphasis on novelty in Christmas church decoration caused suspicion and provoked tensions between the Evangelical and Ritualist parties within the Church of England, as happened at All Saints', Pavement, in York in I858-9. ${ }^{\mathbf{2 9}}$ However, in the last quarter of the nineteenth century both the interest in and controversy surrounding Christmas church decoration gradually declined. In the I87os C. M. Davies, who wrote articles about the religious life of London, commented that the 'time has gone for railing at every little adornment ..., sniffing incipient Popery in every new gaslight, or ritualism in each simple decoration' ${ }^{30}$ Anson estimated that the highly elaborate form of festive church decoration lasted until around I89o, when the gothic style ceased to be fashionable. In the Parson's handbook, first published in I899, Percy Dearmer declared that 'the parson will often have to use his authority to protect the altar from childish attempts at over-decoration', emphasising that extravagance and lack of proportion should be avoided, and that 'plain spaces may be decorated, but not ornament or details'. ${ }^{31}$ However, in Yorkshire there is evidence that at least some parishes were no longer receiving the necessary lay help in terms of either decorating or the supply of materials. It was reported at St Philips and St James, York, that the 'church had to be decorated under great difficulties in procuring either sufficient materials or a sufficient number of workers' during Christmas i89I, and similar problems were reported at St Olave's in the same city in I905. ${ }^{32}$

The place of religion in the popular culture of the expanding Christmas can be further illuminated by examining the attitude of the Protestant Churches to Christmas carols. Medieval in origin, the carol was not necessarily religious or associated with Christmas, though the association with the festive season did increase over time. Despite a large number of carols being printed as cheap broadsheets in the eighteenth century, the early nineteenth century saw a growing interest in Christmas carols amongst antiquarians, who believed that they were relics of a dying folk culture. This in turn provided a foundation for the folk revival of the late nineteenth and early twentieth centuries. ${ }^{33}$ In the early to mid-Victorian period a new body

28 P. F. Anson, Fashions in church furnishing, I840-1940, London I960, 200-2.

29 York Herald, I, 8 Jan. I859; I0, I7 Dec. I859. See also the controversy in the parish of St John the Baptist, Hulme, in Manchester in 1870 : Nigel Yates, Anglican ritualism in Victorian Britain, I830-1910, Oxford I999, I70.

${ }_{30}$ C. M. Davies, Orthodox London: or phases of religious life in the Church of England, London I876, I6o-5.

31 Percy Dearmer, The parson's handbook, London I928, 445-6.

32 St Philip and St James Parish Magazine (Jan. I892); St Olave's Parish Magazine (Jan. I9o6).

${ }^{33}$ Davies Gilbert, Some ancient Christmas carols, with the tunes to which they were formerly sung in the west of England, London I823; William Sandys, Christmas carols, ancient and modern, London I833; Connelly, Christmas, 62-6. 
of Christian-orientated carols emerged, from 'Once in royal David's city' (I848) to 'In the bleak midwinter' (I872), ${ }^{34}$ coinciding with a revival of interest in the carol within the Anglican Church that was part of a broader effort to reclaim a popular aspect of the Christmas festival. One product of this was the publication of collections promoting the use of the carol in church, including J. M. Neale and T. Helmore's Carols for Christmas-tide (1853) and R. R. Chope's Carols for use in church (187I). However, J. A. R. Pimlott has suggested that attempts by the clergy in the 1850 os and I860s to interest their parishioners in a carol revival were too sporadic to be successful, though this changed with the publication of Henry Bramley and John Stainer's Christmas carols new and old (I869). ${ }^{35}$ By the later nineteenth century carol-singing became a regular part of Anglican worship during the Christmas season, particularly during afternoon and evening services. ${ }^{36}$ In 1892 R. R. Chope commented on the 'arduous, prolonged and costly work to restore the use of carols in divine service, and thus make into an act of worship what was wellnigh considered only as a recreation at a social gathering ${ }^{37}$ None the less carol-singing could also be an important part of parish social gatherings as well, and by the end of the nineteenth century many Nonconformist Sunday schools also used them in a social context. ${ }^{38}$ Carols could, however, provoke tension between the Churches and the practitioners of popular custom. Carolling partially overlapped with the tradition of the Christmas waits, where singers perambulated in the late hours of Christmas Eve and the early hours of Christmas Day. In 1892 the vicar of St Saviour's, Leeds, complained that the 'rough and noisy activities ... are none the better for being joined to carols sung in no devotional spirit' ${ }^{39}$ Even when carolsinging was sanctioned, clergymen could attempt to control the practice. In I887 the incumbent of St Philip and St James commented that 'the old custom of singing carols on Christmas Eve was revived this year by members of our own village community, connected with the institute. It would be well ... to confine our patronage to our own people' ${ }^{40}$ By the Edwardian period, this battle for the ownership and control of carolling was given extra stimulus by the folk revival, the proponents of which saw the carol as representative of an authentic Englishness divorced from the traditions of the

${ }^{34}$ John Wolffe, "Praise to the holiest in the height": hymns and church music', in John Wolffe (ed.), Religion in Victorian Britain, Manchester 1997, pp. v, 6I-2; N. Temperley, The music of the English parish church, Cambridge 1979, i. 273.

${ }^{35}$ J. A. R. Pimlott, The Englishman's Christmas: a social history, Hassocks i978, Iog.

36 The Times, 28 Dec. I878; St Saviour's Monthly Paper (Dec. I892); Whitkirk Parish Magazine (Dec. 1898).

37 R. R. Chope, Carols for use in church, London i892, introduction.

38 St Saviour's Monthly Paper (Dec. I892); Pimlott, Englishman's Christmas, I Io.

39 St Saviour's Monthly Paper (Dec. 1892).

40 St Philip and St James Parish Magazine (Dec. I887). 
Church. ${ }^{41}$ As a sympathetic voice argued in The Times in I9Io, a good carol privileged 'frank expression of some personal feeling' over 'the stamp of the theologian'. ${ }^{42}$

Through parish and chapel culture, the Protestant Churches played a formative role in reshaping the way in which Christmas was experienced beyond the family home, though as the evidence demonstrates Anglican parochial festive activities had the potential to militate against the desire for communal unity. In particular, the contest for the control of the carol as a cultural form and carolling as a cultural practice hinted at the hostility which religious organisations could face when addressing matters of custom and the popular meaning of national festivity.

\section{III}

In his study of Victorian and Edwardian Croydon, Jeremy Morris highlights how Anglican churches expanded the provision of worship in the later nineteenth century, and attributes this to the influence of the High Church revival. ${ }^{43}$ In Yorkshire, the evidence suggests that a similar expansion in the number of Christmas services took place. This expansion was not, however, entirely uniform. There was considerable variance between urban and rural locations, with far fewer services taking place in the latter, as well as differences between Evangelical and Ritualist churches. In Leeds, for example, the Evangelical church of St Simon's had only one service on Christmas Day in 1876, whilst the Anglo-Catholic church of St Saviour celebrated holy eucharist at 6, 7 and 8 a.m., Mattins at Io a.m., choral holy eucharist at I0.45 a.m. and evensong at 6.30 p.m.. ${ }^{44}$ According to Morris, further evidence of the 'increasing influence of High Church practices and ideas was the emphasis which came to be placed upon the importance of communion as a vital act of worship' ${ }^{45}$ As Frances Knight notes, one of the most noticeable trends in Sunday worship was the shift from a quarterly to a monthly communion, and again the towns were far in advance of rural parishes. ${ }^{46}$ For Simon Green, this was part of a process in which worship triumphed 'as the characteristic conception of organised religious experience', resulting in communion becoming, as James Obelkevich suggests, 'the test and badge of Anglican commitment ${ }^{2}{ }^{47}$ As Christmas was one of the great festivals of the calendar, Christmas communion was of

\footnotetext{
${ }^{41}$ Connelly, Christmas, ch. iii.

42 The Times, 24 Dec. I910.

43 J. N. Morris, Religion and urban change: Croydon, I840-I9I4, Woodbridge I992, 54.

44 St Simon's Parochial Magazine (Dec. I876); St Saviour's Monthly Paper (Dec. I882).

${ }^{45}$ Morris, Religion and urban change, 55.

46 Frances Knight, The nineteenth-century Church and English society, Cambridge i995, 80.

47 Green, Religion in the age of decline, 295; Obelkevich, Religion and rural society, I27.
} 
significant importance. During Advent, Yorkshire parish magazines offered advice on how to prepare for Christmas communion. At St Olave's, York, parishioners were told to 'feel that in your communion you are going indeed to meet Jesus' and to 'prepare for it a careful self-examination and confession of your sins'. ${ }^{48}$ Such advice was only partially heeded. Evidence from Yorkshire visitation returns and communicant records indicate that Christmas was only a relatively popular time for communion. Whilst some people communicated only at Christmas, it was always second to Easter and could not always guarantee the participation of a parish's more committed Anglicans. ${ }^{49}$ In 1903 the incumbent of Whitkirk near Leeds commented that 'Christmas ... always has many deep disappointments in store for me on account of the absence of so many I hoped to see at the altar'. ${ }^{50}$

Communicant statistics were frequently printed and commented upon in the parish magazines. Late Victorian and Edwardian clergymen measured their communicant statistics against both the standards of Easter and the growing population as a whole. In 1885 John Wylde of St Saviour's declared that he 'cannot imagine what a soul can be like, which, knowing what Holy Communion is, and feeling its necessity at Easter, can put itself out in the darkness of excommunication on the Day of our SAVIOUR'S Birth ${ }^{51}$ In 1907 Charles Bell of St Olave's noted that the number of Christmas communicants had remained steady for many years, but since there were always between sixty and seventy first-communicants added every year, it meant that they were experiencing 'leakage'. However, he added that the 'quality of communicants and not the quantity ... is the thing to be desired', and quoted Charles Gore's observation that 'we don't so much want more Christians, we want better Christians'. ${ }^{52}$ These sentiments reflected the trend highlighted by Frances Knight and Arthur Burns, who argue that the clergy placed increased emphasis on the 'gathered church', 'who were expected to attend the ever-increasing number of, and religiously more demanding, services' rather than the community as a whole. As Knight highlights, this contradicted the vision of the church as the centre of a stable and cohesive parish community. ${ }^{53} \mathrm{In}$ I9I3 Bell demonstrated an awareness of the dissonance between the Anglican view of Christmas communion and popular attitudes towards the festive season when reporting that there were only 535 communicants out of a parish population of 8,000: 'It looks pretty awful when we put it down on

48 St Olave's Parish Magazine (Dec. I894).

49 Borthwick Institute for Archives, York, PR BP.57, Vig12-22; York Minster Library, $\mathrm{S}_{3} / \mathrm{I} / 8, \mathrm{~S}_{4} / 2$ c-e. 50 Whitkirk Parish Magazine (Jan. I903).

51 St Saviour's Monthly Paper (Dec. I885). $\quad{ }_{52}$ St Olave's Parish Magazine (Jan. 1907).

${ }^{53}$ Knight, Nineteenth-century Church, 7I; Arthur Burns, 'The authority of the Church', in Peter Mandler (ed.), Liberty and authority in Victorian Britain, Oxford 2006, 179-202 at p. 192. 
paper doesn't it. And yet I expect all those people or nearly all thought they were keeping Christmas. ${ }^{54}$

Communicant figures are not, however, an accurate guide to attendance at Anglican churches. Those who took the sacrament were usually only a minority of the congregation. Forms of worship were often perceived in terms of class, with communion the preserve of the elite, and attendance at morning or evening prayer being the experience of the common churchgoer. ${ }^{55}$ Church attendance during the Christmas season was higher at the end of the nineteenth century than before; there were more churches and services to attend, and more communions were made, though ultimately this did not keep pace with population growth. In Leeds there was optimism at St Saviour's in the mid-I8gos 'that the due observance of Christmas Day is really gaining ground ${ }^{56}{ }^{56}$ whilst the parish of Whitkirk reported increases in communicants every year from 1903 to 1907 , the figure rising from I8o to $33{ }^{15}{ }^{57}$ Yet the meaning of church attendance at Christmas is more difficult to discern. Christmas and the other great festivals were a strong attraction for the occasional churchgoer, and the nature of that attendance was often inseparable from local customary practice 'in a confusion of sacred and profane activities' ${ }^{58}$ At the same time, attending church was only one of a range of festive leisure options. New Christmas rituals privileged the domestic and familial celebration of the festival, supported by a burgeoning shopping culture. A wide range of theatrical and other entertainments was available, and public houses proved to be a strong draw amongst the working classes. The Church worked hard to compete with the range of leisure activities available by offering equivalent events, but was also challenged in the field of philanthropy by secular associations, whilst rival denominations were increasingly keen to exploit Christmas in terms of worship, charity and social activities.

Another way in which the Established Church sought to emphasise the religiosity of Christmas was to provide additional services in the periods surrounding Christmas Day. Particularly at Anglo-Catholic churches, parishioners were advised to observe Advent as a solemn, meditative period in which the individual should reflect upon the incarnation of Christ and also look forward to his second coming. This Advent sentiment prohibited joyous celebration before Christmas Day; as the vicar of St Olave's stated in I894, 'in Advent we should avoid social festivities as much as lies in our power' ${ }^{59}$ Evening services and special groups were established to promote the Advent message, often featuring visiting speakers, part of the wider move towards the formation of communicants' gilds and associations aimed at

54 St Olave's Parish Magazine (Jan. 1913).

56 St Saviour's Monthly Paper (Jan. 1895).

${ }^{58}$ Robin Gill, The myth of the empty church Green, Religion in an age of decline, 332.
55 Obelkevich, Religion and rural society, I43.

57 Whitkirk Parish Magazine (Jan. I903); (Jan. I907).

London I994, 22; Cox, English churches, I02-3;

59 St Olave's Parish Magazine (Dec. 1894). 
promoting liturgical distinctiveness and intensification as well as solidarity and maintaining religious interest amongst the faithful. ${ }^{60}$ These events do not seem to have been very successful. Commenting on the slender congregations present at the Thursday evening Advent services in I89I, the vicar of St Philip and St James noted that it 'does not encourage the inviting of clergy from a distance on week evenings'. ${ }^{61}$ The disappointment became more pronounced in the Igoos. Special services were abandoned at Whitkirk in I907 as there was 'material enough for everybody if they like to use it' ${ }^{6}{ }^{6}$ Though most families did not begin their Christmas celebration long before Christmas Eve, the message of Advent solemnity ran counter to the prevailing emotional trends in the build-up to Christmas. Already engaged in preparations for Christmas such as shopping, most contemporaries were excited by the prospect of the coming pleasures of the festival season, and could not constrain their feelings within theological frameworks of diligence and watchfulness. By discounting the strong emotional attachment to the customary calendar, the High Church's insistence on the demands of the liturgical year may have unwittingly loosened the place of religiosity within contemporaries' perception of the Christmas festival. Services also proliferated on the saints' days that followed Christmas Day, the most significant being Holy Innocents' Day. It presented an opportunity for the Church to connect its specific concern for the welfare of children to wider notions of childhood innocence that in part Christmas had come to celebrate. Commenting on the introduction of an Innocents' Day service at Westminster Abbey in the early i87os, G. M. Davies noted that 'probably until the present time none ever thought how appropriate it would be to pray and praise as children and have sermons for children, on that day which is so thoroughly their own - Innocents' Day' ${ }^{63}$ In 1870 Whitkirk parish church deliberately held the Sunday scholar's Christmas tree event on Holy Innocents' Day, whilst in I895 St Olave's introduced the annual children's celebration on the same day. ${ }^{64}$

Factions within the Anglican Church proved adept at appropriating distinctive services from denominational rivals, and may form part of what Green has identified as a 'converging system of faiths' in the late nineteenth and early twentieth centuries, though conversely this could also promote 'doctrinal or liturgical demarcation'; as Green explains, 'the narrower these differences actually became, the greater was the temptation for competitively-minded clerics to play them up'. ${ }^{65}$ Midnight services on Christmas Eve, based on the Roman Catholic midnight mass, first appeared under the

\footnotetext{
60 Green, Religion in the age of decline, 309-10; Morris, Religion and urban change, 66-7.

61 St Philip and St James Parish Magazine (Jan. I892).

62 Whitkirk Parish Magazine (Dec. I907). $\quad{ }^{63}$ Davies, Orthodox London, I83-6.

64 Whitkirk Parish Magazine (Jan. I871); St Olave's Parish Magazine (Jan. I898).

${ }^{65}$ Green, Religion in an age of decline, 293-7.
} 
Puseyite regime at St Saviour's, Leeds, in the late $1840 s .{ }^{66}$ However, any appropriation of Roman Catholic ritual by the Church of England remained highly controversial and divisive throughout this period, and in addition to Christmas carolling midnight mass could also be seen to contradict the meaning of Advent promoted by the Established Church in the later nineteenth century. In 1878 The Times reported that the 'habit of midnight communion on Christmas Eve does not seem on the increase', with the exception of churches located in poorer neighbourhoods. ${ }^{67}$ At St Saviour's, John Wylde berated his parishioners, 'it would be a great thing gained if at least all church people would make a point of going to bed in good time on Christmas Eve'. ${ }^{68}$ At St Olave's a Christmas Eve service was not attempted until I909, and here the parishioners were told that 'we must arrange to spend the hours of Christmas Eve from 6pm very quietly' ${ }^{69}$

A less controversial appropriation was the appearance of the Methodistinspired watch-night as an important part of the Christmas seasonal offering in some Anglican churches, a practice which grew rapidly in the midVictorian period. Moravian in origin, watch-nights first appeared in England near Bristol in the I740s, and were quickly endorsed by John Wesley for widespread use amongst Methodists. Although they were first used throughout the year, New Year's Eve emerged as the pre-eminent occasion to observe the watch-night. Lee Eric Schmidt argues that watch-nights presented Evangelicals with the 'potential for pious practice' and provided an expressive vehicle with special 'hymns, exhortations, prayers and testimonials'. The end of the year added urgency to the call to repent, whilst the vigilance of the late hour placed Evangelicals 'in the eschatological framework of being ready for Christ's second coming'. Schmidt interprets the watch-night as a festive alternative to both rowdy street culture and the 'mannered fashions of the genteel' during the festive season. ${ }^{70}$ In 1823 the Wesleyan Methodist Magazine explained the contrast and intent of the watchnight: 'The expiration of the old year, and the commencement of the new one, are too generally seasons of mere dissipation and festivity. Let us pause, and dedicate a little time to serious meditation. It is wise to reflect on the past and to contemplate the future. ${ }^{, 71}$

Though the watch-night service was by nature Evangelical, it was able to permeate the divisions within Anglicanism. Significantly, even the ultraritualistic Church of St Alban's, Holborn, adopted a watch-night service in

\footnotetext{
${ }^{66}$ J. H. Pollen, Narrative of five years at St Saviour's, Leeds, Oxford i851, I03.

67 The Times, 28 Dec. I878. $\quad{ }^{68}$ St Saviour's Monthly Paper (Dec. I892).

69 St Olave's Parish Magazine (Dec. Igog).

${ }^{70}$ Leigh Eric Schmidt, Consumer rites: the buying and selling of American holidays, Princeton I995, II9-2I.

71 Wesleyan Methodist Magazine (Jan. I823).
} 
the early i870s. ${ }^{72}$ Despite watch-nights being adopted by some Anglican churches, they remained an important alternative to the official and popular celebration of Christmas for many Protestant dissenters in the broader context of end of year spiritual practices. In York, for example, the Baptists introduced watch-night services in the I86os as did the Congregationalists in the I870s. ${ }^{73}$ Though there is evidence to suggest that Methodists observed Christmas Day throughout the nineteenth century, Christmas Day services could not be guaranteed within other forms of Protestant dissent unless Christmas Day fell on a Sunday. Only in the second half of the nineteenth century did these churches begin to adopt regular Christmas Day services. For example, the Unitarian Mill Hill Chapel, Leeds, began annual Christmas Day services in the late 1850 s, and introduced additional services in the I880s, whilst in York a special Christmas service took place at Salem Congregational Chapel in I872. ${ }^{74}$ Conversely, when South Parade Baptist Church in Leeds reopened on a new site in 1909, no Christmas Day services took place until $1913 .{ }^{75}$ At the same time, watch-nights were still expanding within Methodism, and a long-established tradition of Methodist watch-nights was not present throughout the country. For example, Green found no evidence of watchnight activity in the area of Halifax, Keighley and Denholme before $1875 .{ }^{76}$

For the early twentieth century there is evidence from south London that shows how watch-nights became intertwined with the culture of the street and the public house. In Southwark, Sarah Williams found that watch-night services could be 'filled to overflowing with those who had left a nearby pub', whilst in Lambeth, Jeffrey Cox notes how bands of youth connected to Christian Endeavour Societies went round the pubs in order to steer the drunken crowds towards the chapel instead of the church. ${ }^{77}$ Watch-nights had become yet another point of competition in the religious marketplace, though both Cox and Williams emphasise that those attending were often motivated by popular beliefs about luck. The desire to be inside a place of worship at the beginning of the year indicates what Williams calls 'spiritual cleansing' and the idea of 'starting the year right', and is closely associated with domestic cleaning rituals and New Year resolutions. Williams views watch-nights as evidence of how 'church-based culture' governed wider elements of everyday life, whilst Simon Green argues that such services reminded people of their connections to places of worship. ${ }^{78}$ Cox, conversely,

72 Davies, Orthodox London, I76-8.

${ }^{73}$ York Herald, 6 Jan. I866; 6 Jan. I872.

${ }^{74}$ Mill Hill Chapel Record (Jan. I858); Mill Hill Chapel Monthly Calendar (Dec. I88I); York Herald, 28 Dec. 1872.

75 South Parade Baptist Church Magazine (Dec. I9I3).

76 Green, Religion in an age of decline, 339-40.

77 Sarah Williams, 'Urban popular religion and the rites of passage', in Hugh McLeod (ed.), European religion in the age of great cities, 1830-I930, London-New York 1995, 216-36 at p. 223; Cox, English churches, I03.

78 Williams, 'Urban popular religion', 223-5; Green, Religion in an age of decline, 340. 
believes that religious institutions were fighting a war 'with the popular religion of "luck", and is supported by evidence from A. B. Bartlett's study of Bermondsey. Bartlett demonstrates that watch-nights were used aggressively by ministers to highlight temperance themes and solemn subjects, but found that there was widespread agreement amongst ministers that watch-night preaching had little long-term effect on congregations, tending to confirm stereotypes in the minds of those attending. ${ }^{79}$ The potential for scepticism amongst both the ministry and the congregation raises the issue of how sincere Edwardian watch-night services were, especially if large sections of the congregation were inebriated. Williams has, however, discovered evidence from IgI3 suggesting that 'it was common for a large number of the congregation to stand and testify to a dramatic conversion experience'. ${ }^{80}$

For some churchmen, the contrast between the excesses of festive drunkenness and the vision of a sanctified Christmas of hearth and home celebrating the qualities of childhood innocence and goodness could lead to extreme reaction against the secular season In Igio the Congregational minister of Salem Chapel, York, addressed the men's open meeting on the afternoon of Christmas Day, and divided the festival along the lines of 'Yuletide or Christmas?', urging his congregation to observe the latter, religious meaning of the festival. ${ }^{81}$ In 1914 Canon Tupper-Carey, addressing a men's service at St Barnabas Church, York, suggested that (the secular) Christmas be abandoned for a short time, because the excessive drunkenness associated with it caused fear and dread to 'hundreds of thousands of mothers and wives'. The issue was taken up by the local press, who pursued other clergymen for their opinions. Charles Bell supported the idea of separation, declaring that 'We have to divide between Christian and heathen', because 'heathen take advantage of the Christmas holiday and behave as heathen'. Bell's use of the word heathen combined common antiquarian parlance for the pagan origins of the Christmas festival with popular imperial and racial discourse linking perceptions of black colonial people and the English working classes in a common savagery. A more tempered response came from P. J. Shaw, vicar of All Saints', North Street in York, who commented that 'You can't make people religious. It must be a voluntary act on their part. The Church must provide them with opportunities to be religious.' Significantly though, Shaw prefaced these comments with the statement that 'outsiders will do differently, that is all', making explicit his belief that his worshippers were an enclosed community ${ }^{82}$ perhaps reflecting the opinion of contemporaries such as Gore and

79 Cox, English churches, I03; Bartlett, 'Churches in Bermondsey', 203.

${ }^{80}$ Williams, 'Urban popular religion', 225.

81 Torkshire Herald, 26 Dec. I9ı.

82 Ibid. 6 Jan. I9I4. 
J. N. Figgis, who rejected the viability of a national Church and argued, in the latter case, that the 'Church must withdraw from the world' ${ }^{83}$

However, it is also important to emphasise that not all churchmen adopted this viewpoint. For example in I9I I the Methodist J. E. Rattenbury argued that the spiritual and material aspects of Christmas were not divorced because all things were made sublime by Jesus. ${ }^{84}$ On occasion the most modern aspects of the English Christmas also proved irresistible to some churchmen. As early as I887 the vicar of St Simon's declared that

Once more we have come to the closing month of another year, and Father Christmas, crowned with holly and crusted all over with snowflakes and icicles, will be peeping at us with his jolly, rosy face. Well, we are always glad to see him. The world has so many sad and painful sights, that even a merry face in itself is a pleasant variation to look upon. ${ }^{85}$

Twenty-five years later the declining opposition of Protestant dissent was demonstrated when a Baptist minister could only articulate his feelings on the nature of Christmas with reference to the secular Scripture of $A$ Christmas carol. Quoting extensively, the minister concluded that 'may we so enter into its spirit with hearts prepared for a large hospitality to Jesus Christ that we shall determine with Ebenezer Scrooge, after his vision, "I will honour Christmas in my heart, and try to keep it all year" ". ${ }^{86}$

This study is necessarily limited, but it demonstrates that religion played a more important role in the formation of the modern English Christmas than recent studies of the festival have allowed, as well illuminating important themes in the popular religious history of the later nineteenth and early twentieth centuries. Though these processes did not occur without cultural contest, the historiography of Christmas in England has tended to downplay the extent to which the Churches participated in the expansion of the urban civic, philanthropic and leisure culture of Christmas in the later nineteenth century. Christmas played a very important role in the vision of the parish as an inclusive organic community, though activities such as church decorating and carolling could reveal the tensions both within the Church and between the sacred and the secular. Perhaps more important, the growing emphasis placed on the doctrine of the incarnation within Anglicanism provided a religious framework for the promotion of the ideologies of childhood and domesticity that Christmas had come to celebrate.

Though internal divisions remained, it is clear that the Established Church regarded the Christmas season as a prime occasion for confirming the loyalty and commitment of its adherents and promoting its vision of an organic

${ }^{83}$ Matthew Grimley, Citizenship, community and the Church of England: liberal Anglican theories of the state between the wars, Oxford 2004, 81.

${ }^{84}$ Freethinker, 24 Dec. г9г. $\quad{ }^{85}$ St Simon's Parochial Magazine (Dec. I887).

86 South Parade Baptist Church Magazine (Dec. I9I2). 
community with the parish church at its heart. These ideals underpinned the expansion of services and social events provided at parochial level and formed part of the broader public culture of Christmas in this period. However, these ideals could provoke contradictory impulses both inclusive and exclusive. Pre-existing tensions between the sacred and the profane were amplified by the discourses of innocence and goodness central to the modern festive celebration of home, family and childhood. Though some special services were not a success, the Church of England did achieve a measure of success in getting more people to attend services and partake of communion at the end of nineteenth century than before, although the comparison of communicant statistics with the broader population could lead to disappointment on the part of clergymen. Though many aspects of the modern Christmas were relatively easy to understand and enjoy within a Christian framework, there were some amongst the clergy who placed emphasis on retaining the support of committed Anglicans rather than the community as a whole. This mindset could result in the perception of a binary opposition between a sacred Christmas and a secular Christmas, particularly when it was confronted with the popular drinking culture of the festive season. Yet, as the evidence of the celebration of the New Year watch-nights in the early twentieth century suggests, spirituality could be present in seemingly unpromising situations. Though the interpretation of this evidence is contested, it demonstrates that the sacred and secular aspects of the Christmas season were more interconnected than the most pessimistic of early twentieth-century churchmen would allow.

The watch-night was both complementary and an alternative to Christmas Day services, potentially forming part of both the Anglican and Nonconformist seasonal offering of worship in the late nineteenth and early twentieth centuries. For Protestant dissenters watch-nights offered a culturally and theologically distinctive mode of marking of the end of year, set against broader tendencies of convergence. By the Edwardian period many Nonconformists displayed a growing acceptance of certain aspects of the festive season, including an increasing willingness to worship on Christmas Day, and more broadly the dissenting Churches played an equal role to the Church of England in the development of the public culture of Christmas in this period. Though David Bebbington argues that the transition from atonement to incarnation did not apply to Protestant Nonconformity, ${ }^{87}$ the strong association of the festive season with childhood undoubtedly contributed to the dissenting acceptance of Christmas, which included the adoption of the new domestic rituals. These developments were crucial to the formation of Christmas as an important part of the national culture of England.

${ }^{87}$ David Bebbington, 'Gospel culture in Victorian nonconformity', in J. Shaw and A. Kreider (eds), Culture and the Nonconformist tradition, Cardiff I999, 43-62 at p. 46. 